\title{
Dispatching and digital solutions as a concept of urban infrastructure in a smart city
}

\author{
O. V. Stepanets, K. N. Nikolaieva, S. V. Lubitskyi, D. A. Kondratenko, D. A. Poputnikov \\ https://doi.org/10.31174/NT2018-158VI18-20
}

National Technical University of Ukraine «Igor Sikorsky Kyiv Polytechnic Institute»

Corresponding author. E-mail: stepanets.av@gmail.com

Paper received 27.01.18; Accepted for publication 05.02.18.

\begin{abstract}
The article describes the concept of a smart city creating with the help of modern devices and solutions in the field of automation. It is based on a research project «Smart-city garbage and logistic systems», created on the basis of the university. It is described the implementation of a dispatch control system by municipal services of the city. The authors also showed how, by means of integrating the management systems of the individual city services, to increase the safety and comfort of residents, improve the management of the lighting system, prevent accidents and provide timely service of the city.
\end{abstract}

Keywords: Smart city, dispatching, control system, logistic, municipal services automation.

Modern cities have accumulated a lot of social, technogenic and ecological problems. That is a reason why cities have become an experimental field for nowadays-digital era. The combination of newest information technologies with urban infrastructure and human services allows us not only to improve life but also to save money [1]. As a fact, Big Data Analysis approaches in monitoring sphere and directly in civil municipal services have become more and more actual.

Moreover, «Smart City» projects have a series of problems that are still unsearched absolutely or they have still on the development stage for solving. These are problems of standardizing protocols, collection and transformation of logged information, ensuring understanding between various departments of infrastructure, creating a single global standard and universal data transformation method. Besides these, the issue of investment is still one of the most important. Especially in small cities, there are typical problems related to the infrastructure readiness to adopt entirely new business models.

It was interesting how to improve life conditions in cities with a help of program technologies solutions, data acquisition and analyzing. It was realized consider some control management systems in smart city. They are street lighting, environmental control system, garbage control system and its logistic collection and intellectual parking.

These solutions enable to reduce a consumption of natural resources, performing the city control system more efficiency. Centralized dispatching help to improve economic performance, by the time systems of smart city also enhance control and security for citizens. There are some solutions presented in the article. They are like program technology examples that demonstrate how a smart city concept could be implemented by separate modules. After that, modules have been integrated into central control system.

Smart cities is a modern trend in cities development [2, 3]. Achievements of progress make it possible to form cyber-physical systems [4] and consider cities as control objects. These can be both individual elements and the integration of a large number of engineering systems.

The components of the smart city is a separate smart decision [5] and complex integration concept [4, 6]. The MK: Smart [6] project uses energy and water consumption information, the urban transport situation, satellite data and social information sources for improving living standards in the city of Milton Keynes, England. Univer- sities, business structures and the municipality interact in this valuable project.

Intelligent parking in the city of Colin, the Czech Republic [5] with the possibility of remote indication of free parking space. Billing can predict city traffic and increased city revenue from parking services up to $120 \%$. Intelligent cars presence sensors in parking spaces, the database of the sensors and the duration of paid parking, visualization system as information boards located next to the parking were used. Everyone is provided with up-todate parking information through a web browser, and the police have a mobile application that informs about violators of parking rules

The analyzed data can be used for urban transformation [6], developing their strengths after analyzing and factors classifying, qualitative and quantitative assessments of the technological solution implementation on energy efficiency and environmental friendliness [8]. Besides these, the development of the intellectual urban infrastructure concept generates the need for new technical and software solutions $[9,10]$ and leads to increasing an attention to security and cyber defense issues [11, 12].

The goal is certainly to create a realistic innovation city model based on using the application of new technologies solutions in automation and networks. Our main idea was to demonstrate modern technologies implementation for city control optimizing and its particular systems. Light control system, environment control system, garbage pollution and logistic control system combined into one management control system. With a help of what it is a great possibility to regulate all existing control systems from a dispatching point and determine alarm mode of a particularly location point in a proper time.

In addition, it is interesting to research how to combine a common electronic sensors and units with enterprise automation and networks. Because of its cooperation, a modern urban infrastructure control system could be implemented and modernized.

The concept of «Smart City» [12] considers the city like the human body. For example, video surveillance system - is like «eyes», sensor network - receptors, executive departments and city services - «the limbs and fingers», transport system - «the blood vessels and arteries». The brain, as an organ of thought - the bodies of municipal management and situational centers, brain and memory - data processing centers (DPC). It is about cre- 
ating more intelligent, busy lifestyles both in urban and in rural areas. Connecting the unconnected, expanding Internet of Everything (IoE) connections and improves the standard of citizens life, quality of education and health care. Human body structure have become so-called prototype for city control systems.

The crucial elements of model is all municipal service trucks. Especially police and garbage collection cars. Because, they have the most frequently truck movement around the city. It is a grate possibility to collect all the information from sensors with a defined period. Then information could be sent to the dispatching center. In our project, we chosen a garbage truck with built in sensors of environment temperature, humidity, noise level, radiation and lighting level. Special checkpoints on the road give a command to the built-in microcontroller to send the measured values to a datacenter (Fig. 1). With a help of GPS navigator operator can define an appropriate checkpoints and perform a program comparison with a current truck location point.

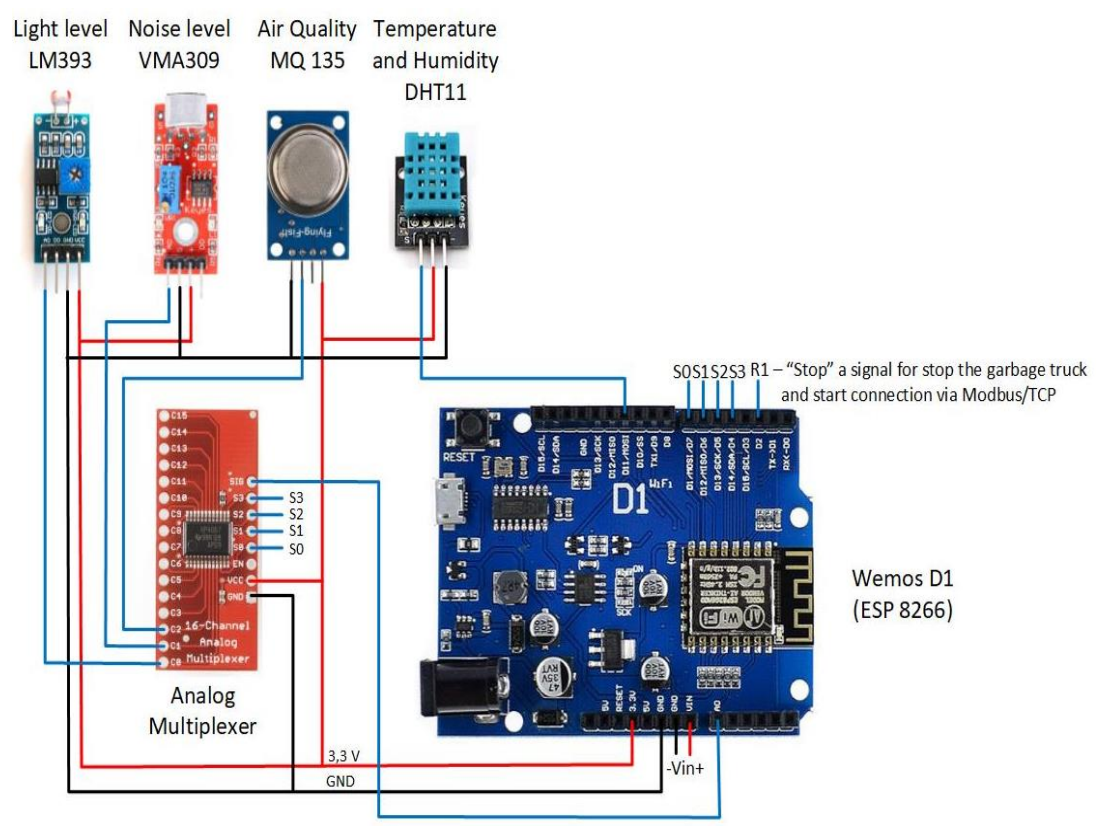

Fig. 1. Garbage truck sensors module

Another control system is lighting. It is not necessary to light on street lamps when the sun light is enough. One more issue is a light intensity. To solve both of these problems the control system of lighting is needed. For its implementation, built-in presence detectors should be used. When somebody or something is standing on the road, an appropriate street lamp is going to increase its light intensity. In this way, government can control the electricity and reduce its consumption. Previously, there was a light level sensor described. It helps to measure a light intensity. When it is not enough, a system help to identify the lamp with an impairment and sent a message to a service center.

One else very important part for residents is a garbage control system (Fig. 2). The most valuable data for this system is the level of the city garbage bins. The measurement of garbage is performed with a help of mounted sensors under the bin covers. They send data to the program controller continuously. That is why dispatcher could know information about city pollution condition. Moreover system could select the an optimize route by the program application. This solution give a possibility to control a traffic and its loading, pollution and to define an element's breakages.

It is always problematic to park your car especially in big cities. That is a reason to mount an intelligent parking control city. Such system is an essential part for integrated city control system. The parking management system has two levels of a logical structure. The lowest is cameras mounted around a parking area. Cameras detect cars and its numbers, and then send data to the server. It is the high structure level. There is a possibility to process received information in a way of web application, then everybody who want to park its car could open an application and define a free places. It can be also a charge parking created with a help of car number recognition. This approach allows combining all the information about parking in one network and enabling drivers to plan their routes, recognizing misdemeanors and damages.

There are often situations with a traffic loading. Sometimes it is happen because of large-tonnage truck. That is why traffic control system with special roadside columns with mounted cameras are needed.

This approach allows you to combine three important aspects:

- optimal moving around the city streets;

- surveillance over the road situation. It increases safety of citizens and speed up the efficiency work of the police in emergencies;

- possibility of more accurate and fair assessment of the road accident situations;

All of the city control systems united into Metropolitan area network (MAN). The main processes are performed in a program controller or Industrial Personal Computer (IPC) installed in the data center.

To visualize all the control systems, conditions of its elements and important values Human Machine Interface system should be implemented. It helps to manage and control remotely all of the city municipals. Dispatcher could know where the municipal cars are and in what 
direction they are moving. The information about the garbage level could be displayed onto the operator screen. With a help of HMI system there is a possibility to check all the control parameters of the city, some statistic data, a truck movement and emergency condition of lights. You can also select working modes (automatic/hand) and make some tests or diagnostics.

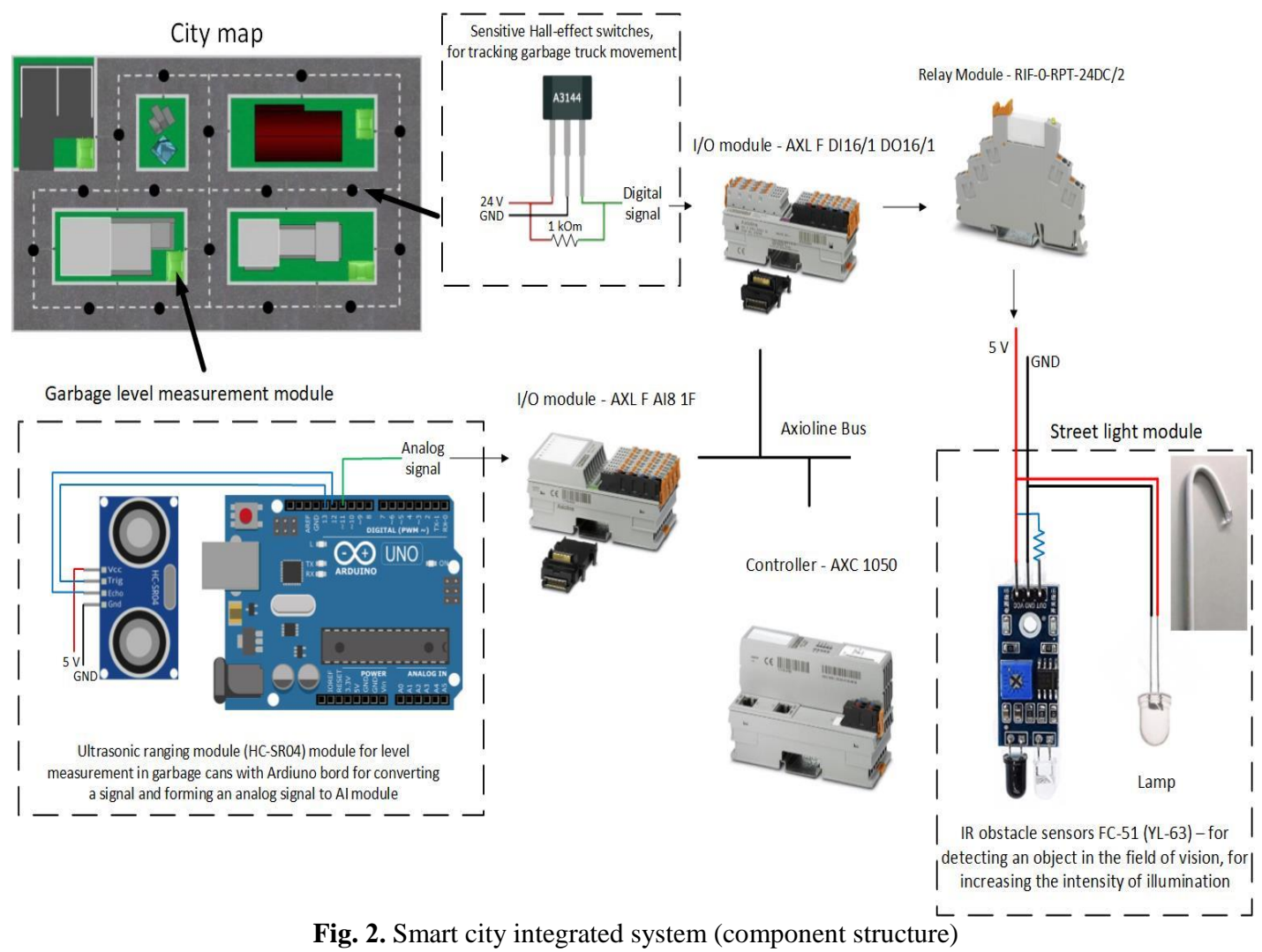

To realize all of these ideas our university ream received an investment from international company Phoenix Contact. The amount was $3000 €$. They supplied us with all necessary automation devices and technical support. Despite of this, near $200 €$ from own department budget have been spent to buy all necessary materials to create a Smart City model. Of course, in real life a total value will be much bigger.

Smart City model described in article is just an example and it could be modernized or integrate into itself some other out-of-article control systems. We have implemented just some control systems in a university model. Intellectual control systems of a smart city are real future. It is important they possess a flexible features to be easy integrated.

It was complicated to implement such a test smart city model. First, it is hard to define an ideal way for data transforming and its protocol. In addition, dispatching center architecture has a significant researching field as a set of technologies. Presented conception is perspective considering of large number different infrastructure elements that have still none automated and connected yet.

Intellectual infrastructure model showed a viability an implementation idea of a widespread industry solutions and new automation approaches interaction. Industries data transformation methods and primary data processing with modern analytical possibilities will credibly reduce an urban infrastructure exploitation value at one time and simultaneously raise a comfort of resident's lives.

In general, it is the completed idea of smart city and it could be customized in a real urban infrastructure with all customer changes and addition control systems.

There are some technologies solutions presented in the article, that promote a centralized control the main city parameters and improve its ecological condition. Such dispatching city control city is very important for a wellbeing of residents. The "Smart City" paradigm is important for modern development cities. In order to optimize significant financial costs during implementation, it is necessary to develop a clear strategy, guided by the priority. However, the implementation of «Smart» technology at the level of municipal-technological unions, in the end, will contribute to the development of the country's economy as a whole, the restoration of outdated enterprises, and the improvement of the conditions for the management of public institutions. This is a real prospect in building a new, intellectual and industrial country.

\section{REFERENSES}

1. Kron A. IoT in the city: today and tomorrow [Electonic resource]:/ Andew Kron // periodic electronic public Geektimes. - Electronic data. - [1th December 2017]. - Mode of access: $p$ (Viewed on $12^{\text {th }}$ January 2018). - Title from screen.

2. Eremia, M., Toma, L., Sanduleac, M. (2017). The smart city concept in the 21th century. Procedia Engineering,
181(2017), 12 - 19. DOI: 10.1016/j.proeng.2017.02.357

3. Airaksinen, M., Kokkala, M. (2015). Smart City Research Highlights. Finland: VTT Technical Research Centre of Finland, 134.

4. Cassandras, C. (2016). Smart Cities as Cyber-Physical Social Systems. Engineering, 2(2), 156-158. DOI: 
10.1016/J.ENG.2016.02.012

5. mySCADA. Smart parking. (2016, September 1). Retrieved from http://myscada.org/wp-content/uploads/downloads/ references /RF_Smart_Parking_EN.pdf

6. Caird, S. with Hudson, L. and Kortuem, G. (2016) A Tale of Evaluation and Reporting in UK Smart Cities. 51pp. The Open University, UK.

7. Zotano, M. A. G., Bersini, H. (2017). A data-driven approach to assess the potential of Smart Cities: the case of open data for Brussels Capital Region. Energy Procedia, 111(2017), 750 - 758. DOI: 10.1016/j.egypro.2017.03.237

8. Girardi, P., Temporelli, A. (2017). Smartainability: a methodology for assessing the sustainability of the smart city. Energy Procedia, 111(2017), 810 - 816. DOI: 10.1016/j.egypro.2017.03.243

9. Zhuhadar, L, Thrasher, E., Marklin, S., de Pablos, P.O. (2017). The next wave of innovation - Review of smart cities intelligent operation systems. Computers in Human Behavior, 66 (2017), 273-281. DOI: 10.1016/j.chb.2016.09.030.

10. Sujataa, J., Sakshamb, S. Tanvic, G., Shreya. (2016). Developing Smart Cities: An Integrated Framework. Procedia Computer Science, 93(2016), 902-909. DOI: 10.1016/J.ENG.2016.02.012

11. Lévy-Bencheton, C., Darra, E., Bachlechner, D., Friedewald, M., et al.. (2015). Cyber Security for Smart Cities - an Architecture Model for Public Transport. Heraklion, Greece: ENICA. DOI: $10.2824 / 846575$

12. Ijaz, S., Shah, M.A., Khan, A., Ahmed, M. (2016). Smart Cities: A Survey on Security Concerns. International Journal of Advanced Computer Science and Applications, 7(2), 612-625.

13. Shalahynov A.V. Solution «Smart garden» (Smart City) [Text] / A.V. Shalahynov // Magazine IT-Manager. 2015. №9. P. 10-11

\section{Dispatching and digital solutions as a concept of urban infrastructure in a smart city}

O. V. Stepanets, K. N. Nikolaieva, S. V. Lubitskyi, D. A. Kondratenko, D. A. Poputnikov

Abstract. The article describes the concept of a smart city creating with the help of modern devices and solutions in the field of automation. It is based on a research project «Smart-city garbage and logistic systems», created on the basis of the university. It is described the implementation of a dispatch control system by municipal services of the city. The authors also showed how, by means of integrating the management systems of the individual city services, to increase the safety and comfort of residents, improve the management of the lighting system, prevent accidents and provide timely service of the city.

Keywords: Smart city, dispatching, control system, logistic, municipal services automation.

Дигитализация и цифровые решения как концепции уличной инфраструктуры умного города А. В. Степанец, Е. А. Николаева, С. В. Любицкий, Д. А. Кондратенко, Д. А. Попутников

Аннотация. В статье рассмотрена концепция создания умного города с помощью современных средств и решений в сфере автоматизации. За основу взят научно-исследовательский проект «Smart-city garbage and logistic systems», созданный на базе университета. Описана реализация системы диспетчерского контроля муниципальными службами города. Также авторами было показано, как с помощью интеграции систем управления отдельных служб жизнедеятельности города можно повысить безопасность и комфорт жителей, повысить эффективность управления системой освещения, предотвращать аварии и оказывать своевременное сервисное обслуживание города.

Ключевые слова: Умный город, диспетчеризация, система управления, логистика, автоматизация муниципальных служб. 